\title{
KAJIAN FISIOLOGIS KERING ALUR SADAP PADA TANAMAN KARET (Hevea brasiliensis)
}

\author{
Physiological Study of Tapping Panel Dryness in Rubber (Hevea brasiliensis)
}

Mudita Oktorina Nugrahani, Akhmad Rouf, Intan Berlian, dan Hananto Hadi

\author{
Balai Penelitian Getas \\ J1. Pattimura Km. 6 Po Box 804 Getas, Salatiga, 50702 \\ Email: mudita.nugrahani@balitgetas.co.id
}

Diterima 6 Desember 2015 / Direvisi 2 Mei 2016 / Disetujui 20 Mei 2016

\begin{abstract}
Abstrak
Kering Alur Sadap ( KAS) merupakan salah satu gangguan fisiologis pada tanaman karet. Gejala serangan penyakit ini umumnya ditandai dengan terhentinya aliran lateks dan mengeringnya bidang sadap. Penyebab utama terjadinya KAS adalah adanya gangguan pada sistem pembuluh lateks sehingga memicu terbentuknya senyawa-senyawa radikal tertentu yang dapat menyebabkan terjadinya kerusakan lutoid. Ketika lutoid pecah terjadi proses koagulasi lateks dalam pembuluh lateks. Koagulasi tersebut menjadi penyebab terbentuknya jaringan tilasoid, tersumbatnya pembuluh lateks, dan akhirnya lateks tidak dapat mengalir pada saat disadap. Pemilihan klon yang sesuai, penerapan sistem sadap normatif sesuai tipologi klon, pemeliharaan tanaman yang lebih baik dan pengawasan dini adalah upaya pencegahan yang dapat dilakukan untuk menangani serangan KAS.
\end{abstract}

Kata Kunci: KAS, Fisiologis lateks, Tanaman Karet

\section{Abstract}

The Tapping Panel Dryness (TPD) is a physiological disease in rubber plant. Generally, the symptoms of this disease had characterized by the interruption of the latex flow and dried of tapping panel. The main cause of TPD was disturbanced on the latex system, so as triggered of the formation of radicals specific compounds that could be caused lutoid damage. When, the lutoid broken will be occurs latex coagulation processed in the latex vessels. The coagulation to be caused of tilasoid tissue form, plugging of latex vessel, and finally latex could not flow at tapped. The selected of suitable clones, applicated of normative tapping system based on clone typologies, maintenanced a good plant and early controled were prevented efforts which could be done to protect of TPD attack.

Keywords: TPD, Latex physiology, Rubber

\section{Pendahuluan}

Kering alur sadap (KAS) adalah gangguan fisiologis yang mengakibatkan tanaman karet (Hevea brasiliensis Muell. Arg) tidak mampu mengeluarkan lateks pada saat dilakukan penyadapan karena terjadi penyumbatan pada jaringan pembuluh lateks. Tersumbatnya aliran lateks disebabkan oleh pembekuan lateks dan terbentuknya sel tilosoid dalam jaringan pembuluh lateks (Siswanto, 1997). Terbentuknya sel tilasoid tersebut diinduksi oleh adanya penurunan permeabilitas dinding sel pembuluh lateks. Penurunan permeabilitas dinding sel ini akibat adanya intensitas sadap yang cukup tinggi (Sivakumaran et al., 2002). Beberapa penelitian terdahulu menjelaskan bahwa kejadian tersebut berkaitan dengan frekuensi atau intensitas sadap tinggi (overtapping) yang berlangsung dalam jangka waktu lama (Paranjothy et al., 1976; dan Vijayakumar et al., 1991). Penyadapan dengan intensitas berlebihan atau overtapping menyebabkan lateks yang dipanen tidak dapat diimbangi oleh kemampuan tanaman untuk meregenerasikan lateks. 
Secara morfologi gejala KAS diawali oleh terjadinya perlambatan aliran lateks, penurunan kadar karet kering (KKK), dan kekeringan pada sebagian alur sadap atau disebut KAS sebagian (parsial). Apabila hal itu berlanjut, alur sadap akan mengering, kulit mengalami nekrosis, dan akhirnya pecah pecah (Dey, 2005). Kejadian ini sering disebut sebagai KAS total. Pada kasus KAS parsial, tanaman yang diperlakukan dengan istirahat sadap selama beberapa waktu (rest period) akan kembali sehat sehingga dapat disadap kembali. Sebaliknya tanaman yang mengalami KAS total, bidang sadap tidak dapat mengalirkan lateks seperti semula sebelum terjadi regenerasi kulit baru.

Karena tuntutan produksi, tanaman yang mengalami KAS seringkali tetap disadap, yaitu dengan menyadap kulit batang pada panel lain yang dapat mengeluarkan lateks. Hal ini menyebabkan umur ekonomis tanaman karet menjadi semakin pendek yaitu kurang dari 20 tahun. Padahal periode penyadapan seharusnya dapat berlangsung antara 20 hingga 25 tahun. George et al., (2005) menyatakan bahwa kejadian KAS selain berdampak pada berkurangnya umur ekonomis tanaman juga memunculkan akumulasi kerugian, baik pada aspek manajemen tanaman maupun produktivitas kebun. Menurut Prawirosoemardjo dan Setyawan (2010), kerugian finansial akibat KAS mencapai lebih dari 10 milyar per tahun dan kerugian tersebut dapat bervariasi sesuai dengan persentase pohon.

Oleh karena besarnya potensi kerugian yang ditimbulkan, maka perlu pemahaman baik secara fisiologis maupun teknis mengenai kejadian KAS bagi para pelaku perkebunan karet. Selain itu, pencegahan, penanganan dan penyembuhan KAS merupakan upaya penting yang harus dilakukan untuk meminimalisir.

\section{Penyadapan dan Kering Alur Sadap}

Prinsip penyadapan yang baik adalah mengambil lateks yang sudah mengalami proses regenerasi sempurna di dalam pembuluh lateks. Penyadapan dengan intensitas berlebihan atau over tapping berarti mengeluarkan lateks sebelum lateks teregenerasi secara sempurna, sehingga akan berdampak negatif terhadap tanaman. Overtapping tersebut dapat terjadi karena periode sadap lebih pendek, atau pemberian stimulan yang berlebihan. Ketidakseimbangan antara lateks yang diambil dengan lateks yang diregenerasikan akan menyebabkan tanaman mengalami kelelahan fisiologis. Hal tersebut dapat bersifat sementara, sehingga kesehatan tanaman dapat kembali normal apabila penyadapan diistirahatkan untuk sementara waktu. Meskipun demikian jika intensitas penyadapan tetap tinggi, maka gejala tersebut akan menyebabkan kondisi kulit batang mengering atau KAS permanen. Gejala KAS ditandai dengan tidak mengalirnya lateks apabila tanaman karet disadap. Secara histologis gejala awal KAS ditandai dengan adanya koagulasi lateks dan pembentukan sel tilasoid (Siswanto et al., 2004; Andriyanto dan Tistama, 2014). Secara morfologis tanaman yang menderita KAS berat masih dapat tumbuh dengan baik, tetapi kulit bidang sadap mengering, mengelupas, dan pecah-pecah (Prawirosoemardjo dan Setyawan, 2010). Kulit batang yang pecah-pecah karena terserang KAS memiliki tekstur keras dan terlihat kering (Gambar 1A), biasanya terjadi pada area di bawah alur sadap, namun kadang terjadi di atas alur sadap. Pada Gambar 1A juga menunjukkan bahwa lateks tidak keluar sepenuhnya di sepanjang alur sadap. Apabila dilakukan pengerokan pada bagian kulit yang mengalami KAS maka akan ditemukan adanya jaringan mati berwarna kecokelatan (Gambar 1B).

Secara mikroskopis, KAS ditandai dengan rusaknya membran inti sel dan membran lutoid, terbentuknya globula jernih dalam sel tanin, dan pembentukan tilosoid dalam sel pembuluh lateks. Kondisi tersebut menyebabkan terjadinya penutupan jaringan pembuluh lateks sehingga lateks tidak dapat mengalir (Prawirosoemardjo dan Setyawan, 2010).

Selain itu, gejala fisiologis yang muncul adalah adanya penurunan kadar karet kering 


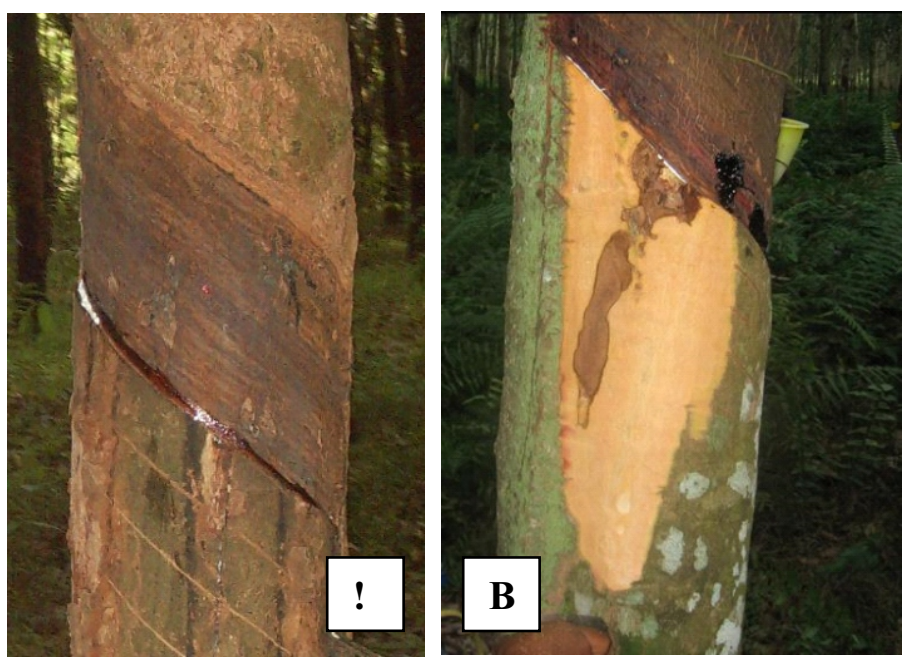

Gambar 1. Gejala KAS. (A) kulit bertekstur keras dan kering, serta sebagian alur sadap tidak mengeluarkan lateks. (B) Jaringan kulit tanaman KAS berwarna kecokelatan.

di dalam lateks. Jacob et al. (1989) menyatakan kadar karet kering menjadi rendah karena tanaman disadap ulang sebelum proses regenerasi lateks berlangsung sempurna. Dalam proses regenerasi lateks, sukrosa merupakan bahan baku untuk pembentukan partikel karet. Kandungan sukrosa yang tinggi menunjukkan adanya influks yang baik ke dalam sel pembuluh lateks, namun hal tersebut menyebabkan tanaman menjadi rawan KAS jika disadap berlebihan. Hasil penelitian Tistama et al. (2006) menunjukkan kandungan sukrosa pada tanaman yang terserang KAS parsial jumlahnya lebih tinggi dibandingkan tanaman sehat. Hal tersebut disebabkan karena suplai sukrosa berlangsung normal namun terjadi hambatan dalam proses regenerasi lateks yang mengakibatkan sukrosa tidak dapat dimanfaatkan dan terjadi penumpukan. Kandungan sukrosa akan mengalami penurunan dengan meningkatnya intensitas penyadapan. Penurunan ini disebabkan proses biosintesis karet semakin aktif dan membutuhkan semakin banyak sukrosa yang harus diubah menjadi partikel karet.

\section{Mekanisme Fisiologi Kering Alur Sadap}

Penyadapan dan penambahan stimulan pada tanaman karet akan direspons oleh tanaman sebagai cekaman bagi kehidupannya. Cekaman lingkungan akan menyebabkan akumulasi Reactive Oxygen Species (ROS) yang dapat menghancurkan makromolekul penyusun membran organel atau sel. Kerusakan membran tersebut akan memicu kematian sel. Untuk mengatasi cekaman tersebut, tanaman karet meningkatkan aktivitas askorbat peroksidase (APX; EC 1.11.1.9). Enzim tersebut berperan dalam detoksifikasi ROS in vivo, dan berperan dalam ketahanan terhadap cekaman dan mengatur lamanya aliran lateks (Tjoet et al., 2002).

Secara umum aliran lateks akan terhenti dan menjadi kering alur sadap (KAS) saat tingkat eksploitasi melebihi kapasitas pohon untuk meregenarasi lateks (Jacob et al. ,1994). Pada umumnya kondisi tersebut terjadi karena intensitas sadap tinggi dan aplikasi stimulan. Intensitas sadap tinggi dan penggunaan stimulan berlebih merupakan sebuah fenomena cekaman oksidatif bagi tanaman 
karet. Cekaman oksidatif merupakan kerusakan yang diakibatkan oleh $\mathrm{O}_{2}$ dan radikalnya (Alscher et al., 2002). Cekaman oksidatif telah diketahui mengubah jalur metabolisme normal di jaringan sehat dengan cara memicu rentetan proses degeneratif (Krishnakumar, 2005). Hal tersebut dapat menyebabkan lateks terus mengalir dan serum lateks banyak keluar, sehingga mengakibatkan sel-sel pembuluh lateks mengalami kelelahan fisiologis.

Proses degeneratif yang terjadi memicu aktivitas enzim - enzim tertentu untuk membentuk senyawa radikal bebas, seperti $\mathrm{O}_{2}$, $\mathrm{OH}^{-}$. Senyawa tersebut menyebabkan membran inti sel dan membran lutoid mudah rusak, sehingga terjadi koagulasi lateks dalam jaringan pembuluh lateks (Tistama et al., 2006). Hal tersebut sesuai dengan pernyataan Chrestin (1989) bahwa terjadinya koagulasi dalam pembuluh lateks disebabkan oleh adanya degradasi membran lutoid oleh senyawa $\mathrm{ROS}$ seperti $\mathrm{O}_{2}^{-}, \mathrm{H}_{2} \mathrm{O}_{2}, \mathrm{OH}^{*}$ dan $\mathrm{QO}^{*}$ selanjutnya senyawa yang terkandung dalam lutoid akan dibebaskan sehingga menyebabkan koagulasi. Faktor yang berpengaruh positif terhadap kestabilan membran lutoid adalah enzim SOD dan katalase serta senyawa tiol dan asam askorbat yang bisa menetralkan senyawa ROS tersebut (Siswanto, 1994). Superoksida $\left(\mathrm{O}_{2}{ }^{-}\right)$disintesis oleh NAD(P)H oksidase pada membran lutoid sedangkan $\mathrm{QO}^{*}$ oleh peroksidase sitosolik (Gambar 2).
Superoksida secara non enzimatik membentuk $\mathrm{OH}^{*}$ atau secara enzimatik oleh SOD akan diubah menjadi $\mathrm{H}_{2} \mathrm{O}_{2}$ dan selanjutnya oleh katalase akan dinetralkan menjadi $\mathrm{H}_{2} \mathrm{O}$ dan 1/2O2 oleh katalase (Chrestin, 1989 ; Siswanto, 1994).

Kerusakan membran yang menyebabkan lutoid pecah, menjadikan senyawa yang bersifat asam tersebut menyebar dalam sitosol sel, sehingga terjadi penurunan $\mathrm{pH}$. Penurunan $\mathrm{pH}$ tersebut mengakibatkan terjadinya koagulasi di dalam sel pembuluh lateks melalui pembentukan matriks-matriks partikel karet (Gomez et al., 1990). Di sisi lain, terbentuknya radikal bebas menyebabkan reaksi biokimia dan metabolisme sel serta fungsi enzim tersebut terganggu, sehingga terjadi penumpukan sukrosa, HMG CoA dan Mevalonat (Gambar 3). Penelitian Krishnakumar et al. (2001) menunjukkan bahwa tanaman KAS akan mengalami perubahan mevalonat menjadi isopentenil pirofosfat (IPP) akibat dari rendahnya suplai ATP. Tistama et al. (2006) juga menyatakan bahwa kandungan sukrosa, HMG-Co A dan mevalonat pada tanaman sehat umumnya lebih rendah dibanding tanaman yang mengalami gangguan KAS, sedangkan pada tanaman yang sehat kandungan $\mathrm{Pi}$, tiol dan ATP cenderung lebih tinggi dibanding tanaman yang mengalami gangguan KAS.

Hal tersebut diduga terjadi gangguan biosintesis lateks karena kurangnya suplai ATP ke dalam pembuluh lateks.

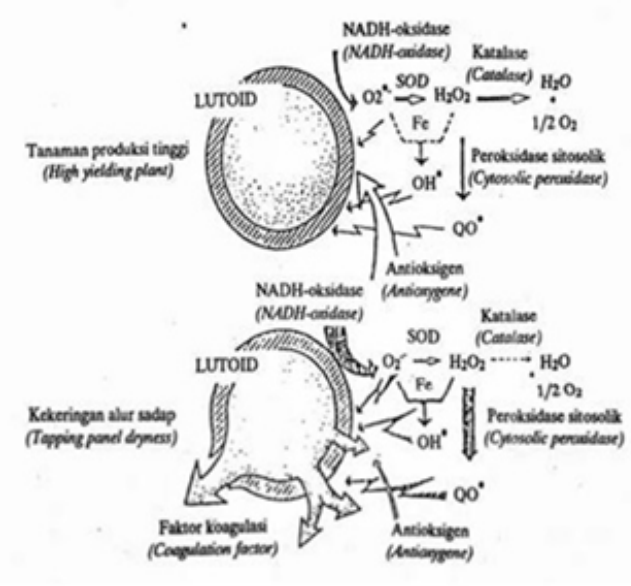

Gambar 2. Skema degradasi membran lutoid dari tanaman karet yang mengalami KAS Sumber: Siswanto, 1994. 


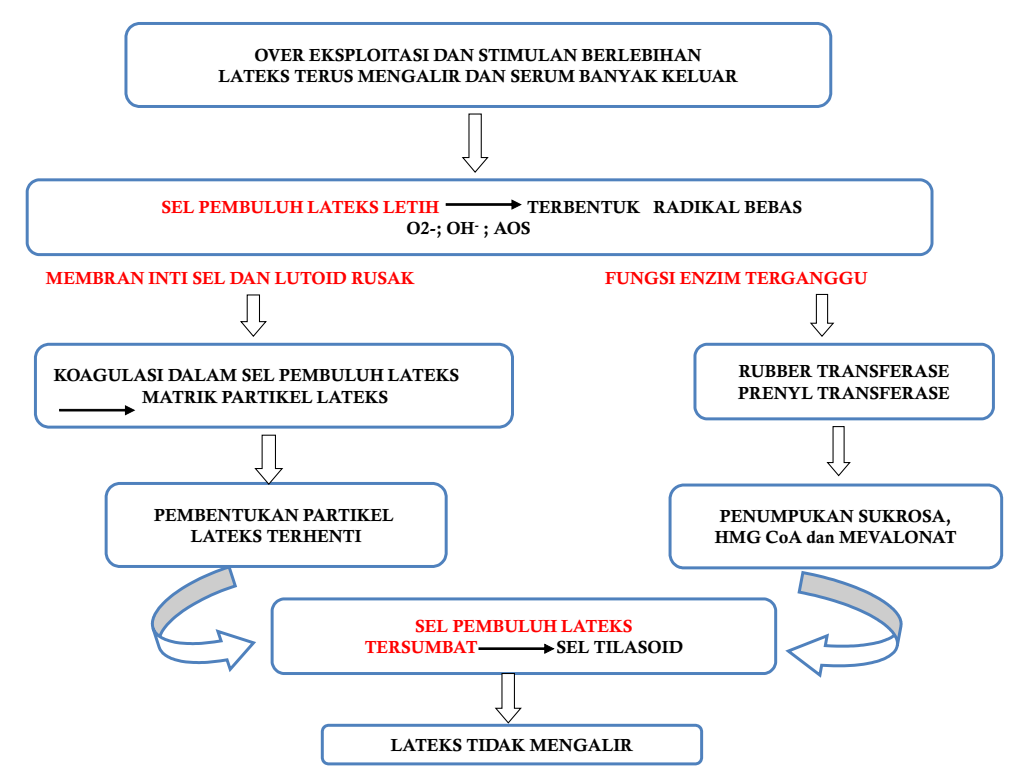

Gambar 3. Skema mekanisme terhentinya aliran lateks Sumber: Hadi, 2008.

Krishnakumar et al. (2001) menambahkan bahwa ATP tersebut adalah sumber energi utama pada proses reaksi IPP menjadi mevalonat. ATP yang rendah juga diikuti oleh kandungan fosfat anorganik (Pi) yang rendah pada tanaman yang mengalami KAS. Umumnya kandungan $\mathrm{Pi}$ cenderung mengalami penurunan apabila tanaman terusmenerus disadap dengan intensitas tinggi. Semakin tinggi intesitas penyadapan semakin rendah pula kandungan tiol (R-SH) dalam lateks. Tiol merupakan salah satu komponen fisiologi penting lainnya dalam lateks. Peran tiol terkait dengan pengaktifan enzim - enzim yang berhubungan dengan cekaman lingkungan. Jacob et al. (1989) menerangkan bahwa tiol berfungsi untuk menjaga stabilitas membran lutoid dengan menetralisir senyawa oksigen toksik. Apabila kandungan tiol rendah dapat menurunkan stabilitas lutoid yang dapat memicu kerusakan membran lutoid.

Kondisi tersebut menyebabkan sel pembuluh lateks mengalami penyumbatan dan menjadi sel tilosoid. Sel-sel tilosoid kemudian melebar ke arah sel-sel yang lain dan semakin meluas, sehingga akhirnya kulit tersebut mati dan lateks tidak mengalir (Gambar 3). Bidang sadap yang memiliki jaringan tilosoid ini pada awalnya hanya menunjukkan KAS parsial, dan akan berkembang menjadi KAS total jika overtapping. Pengamatan morfologi dan histologi pada jaringan kulit karet menunjukkan bahwa pembentukan sel tilosoid di dalam pembuluh lateks yang terjadi akibat penyimpangan fisiologi menyebabkan terganggunya proses regenerasi lateks (Gomez, et al., 1990). Dengan demikian, penyembuhan tidak akan terjadi selama belum terbentuknya jaringan kulit baru yang berisi sel-sel pembuluh lateks baru. Oleh karena itu perlu dilakukan pengerokan pada kulit bagian luar agar cepat terbentuk jaringan kulit baru. Menurut Tistama et al. (2006) pengerokan atau scraping tersebut dilakukan untuk membuang jaringan tilasoid yang menghambat pembuluh lateks, sehingga dapat tumbuh jaringan kulit baru yang produktif. 


\section{Faktor-Faktor Pengaruh Kering Alur Sadap}

Berdasarkan pengamatan di lapangan, variasi intensitas KAS yang terjadi pada beberapa perkebunan karet dipengaruhi oleh beberapa faktor, antara lain: jenis klon, intensitas sadap (sistem sadap dan penggunaan stimulansia), tata guna kulit, ketersediaan hara bagi tanaman.

\section{Klon}

Setiap klon memiliki sifat yang berbedabeda dalam merespon penyadapan baik terhadap intensitas sadap, respon terhadap stimulan, hasil pertumbuhan kulit pulihan dan sebagainya. Siregar et al. (2008) dan Sumarmadji et al. (2012) menyampaikan bahwa jenis klon dengan sifat metabolisme tinggi (quick starter) memiliki sifat rentan terhadap KAS dan kurang responsif terhadap pemberian stimulan. Pengaruh pemberian stimulan spesifik pada tanaman karet berkaitan luas dengan reaksi-reaksi enzimatis yang kompleks (Sumarmadji et al., 2004). Pada klon dengan sifat metabolisme tinggi, sebagian besar asimilat dipergunakan untuk biosintesis lateks, sedangkan proporsi asimilat untuk pertumbuhan dan pertahanan tanaman rendah. Akibatnya, pengeluaran lateks yang berlebihan menyebabkan ketahanan fisiologis tanaman menurun. Hal tersebut memicu mekanisme fisiologis tanaman untuk bertahan hidup dengan cara penghentian lateks melalui proses koagulasi lateks dalam sel-sel pembuluh lateks. Jenis klon yang cenderung tahan terhadap tekanan eksploitasi tinggi dan responsif terhadap stimulan adalah klon dengan metabolisme rendah (slow starter). Contoh klon quick starter antara lain PB 260, PB 340, IRR 112 dan IRR 118, sedangkan klon slow starter antara lain BPM 1, BPM 24, GT 1, PR 300, PR 303 dan RRIC 100.

Penelitian di Agratala India yang dilakukan oleh Dey (2005) pada beberapa klon anjuran dan beberapa tanaman karet poliklonal menunjukkan bahwa hampir semua tanaman tersebut dapat mengalami kering alur sadap. Beberapa tanaman klonal yang telah diamati mengalami persentase kering alur sadap total antara kisaran 2,7-15,7\% (telah disajikan pada Tabel 1). Kejadian KAS paling banyak dijumpai di panel B1-1, kemudian B0-2 dan B0-1. Hal ini menunjukkan bahwa meskipun sebagian besar KAS muncul pada kulit pulihan, tetapi KAS juga dapat terjadi pada kulit perawan (B0).

Tabel 1. Persentase tanaman yang mengalami kering alur sadap total pada beragam bidang sadap dari beberapa jenis klon

\begin{tabular}{lccc}
\hline \multirow{2}{*}{ Klon } & \multicolumn{3}{c}{ Intensitas KAS (\%) pada berbagai bidang sadap } \\
\cline { 2 - 4 } & BO-1 & BO-2 & B1-1 \\
\hline PB 235 & 7,1 & 10,6 & 15,7 \\
RRII 203 & 3,2 & 4,5 & 7,6 \\
RRIM 600 & 4,1 & 6,0 & 8,8 \\
RRII 118 & 3,4 & 4,3 & 7,4 \\
RRIM 703 & 4,1 & 4,3 & 8,6 \\
RRII 705 & 4,7 & 9,6 & 12,7 \\
PB 86 & 2,7 & 3,0 & 6,8 \\
RRIC 105 & 7,6 & 9,5 & 10,0 \\
RRIM 105 & 5,0 & 9,0 & 10,4 \\
GT 1 & 3,7 & 8,3 & 8,6 \\
RRII 5 & 4,7 & 5,2 & 6,0 \\
RRIC 52 & 5,2 & 5,2 & 8,3 \\
PB 5/51 & 3,4 & 6,8 & 6,8 \\
HARBEL 1 & 4,3 & 8,6 & 9,0 \\
GL 1 & 3,0 & 10,0 & 12,3 \\
\hline
\end{tabular}

Sumber: Dey, 2005 


\section{Stimulan dan intensitas sadap}

Pemberian stimulan yang berlebihan akan dianggap sebagai cekaman bagi tanaman hingga senyawa toksis ROS seperti, superoksida dan radikal hidroksil muncul sebagai pemberi pesan keadaan yang dialami oleh tanaman tersebut. Enzim HbAPX1 hadir untuk menetralisir toksisitas yang ada dengan diaktivasi oleh senyawa tiol (Chrestin, 1989). Menurut Nair et al. (2004) konsentrasi tiol semakin turun dengan adanya perlakuan stimulan.

Paranjothy et al. (1976) menyatakan penggunaan stimulan cair berbahan aktif etephon yang berlebihan dapat menginduksi terjadinya penyimpangan proses metabolisme, seperti penebalan kulit batang, nekrosis, terbentuknya retakan pada kulit, dan timbulnya bagian tidak produktif pada irisan sadap. Pemakaian etefon berlebihan juga mengakibatkan berhentinya aliran lateks yang disebabkan oleh koagulasi partikel karet di dalam sel pembuluh lateks (Tistama dan Siregar, 2005).

Timbulnya penyakit KAS akan meningkat sebanding dengan tingginya frekuensi penyadapan (Vijayakumar et al., 1991) dan pemberian stimulan etefon yang berlebihan (Chrestin, 1989). Menurut Jacob et al. (1994) semakin pendek interval penyadapan akan berpengaruh terhadap regenerasi organ sel sel tertentu yang mampu menjadi pemicu munculnya gejala KAS. Hal tersebut membuktikan peningkatan intensitas penyadapan (overtapping) berpengaruh signifikan terhadap peningkatan metabolisme sel yang dapat memicu kemunculan KAS.

\section{Tataguna panel}

Tataguna panel dapat berpengaruh terhadap kejadian KAS jika penyadapan dilakukan pada panel tertentu tanpa memperhatikan kesinambungan aliran dan translokasi lateks sehingga jaringan lateks terputus. Tupy (1989) menyampaikan bahwa bahan dasar lateks berupa asimilat dari hasil fotosintesis akan ditranslokasikan dari daun ke jaringan floem. Dalam hal ini daun berfungsi sebagai tempat diprosesnya sumber asimilat (source), sedangkan jaringan floem sebagai tempat penerima asimilat (sink). Apabila source dan sink berhubungan langsung atau tidak terputus, maka proses translokasi lateks dan regenerasi lateks dapat berlangsung dengan baik, serta berdampak positif terhadap perolehan produksi.

Pada penyadapan $\mathrm{S} / 2$ ke arah bawah (SKB), misalnya pada panel B0-1, arah aliran lateks bermula dari daun sebagai sumber asimilat (source) lalu ditranslokasikan ke panel yang berhubungan langsung dengan source yaitu B0-2, kemudian asimilat tersebut ditranslokasikan ke panel sebelahnya yang disadap (berperan sebagai sink) yaitu B0-1. Apabila penyadapan dilakukan pada kedua panel dalam waktu yang berdekatan tanpa ada pemulihan kulit, maka mengakibatkan hubungan antara source dan sink terputus dan berdampak pada panel di bawahnya menjadi kering atau terjadi KAS (Gambar 4A dan B). Penyadapan pada panel yang berlawanan misalnya di B0-2 dan $\mathrm{H} 0-1$ juga dapat menyebabkan aliran lateks terputus dan berpotensi menyebabkan KAS pada panel bawah (Gambar 4C) (Hadi, 2008).

\section{Keseimbangan hara}

Serapan hara yang tidak efektif dan ketidakseimbangan nutrisi merupakan salah satu faktor penyebab munculnya KAS (Pushpadas et al., 1975). Berdasarkan kajian dari Sivakumaran et al. (2002) diketahui bahwa tanaman yang mengalami gangguan KAS dapat diidentifikasi dari kandungan unsur hara makro dan mikro dalam lateks. Tanaman yang mengalami KAS akan memiliki kandungan unsur hara yang cenderung lebih rendah dibandingkan tanaman yang sehat. Meskipun demikian tidak ditemukan perbedaan signifikan mengenai kebutuhan unsur hara makro dan mikro pada tanaman karet sehat maupun yang terserang KAS. 

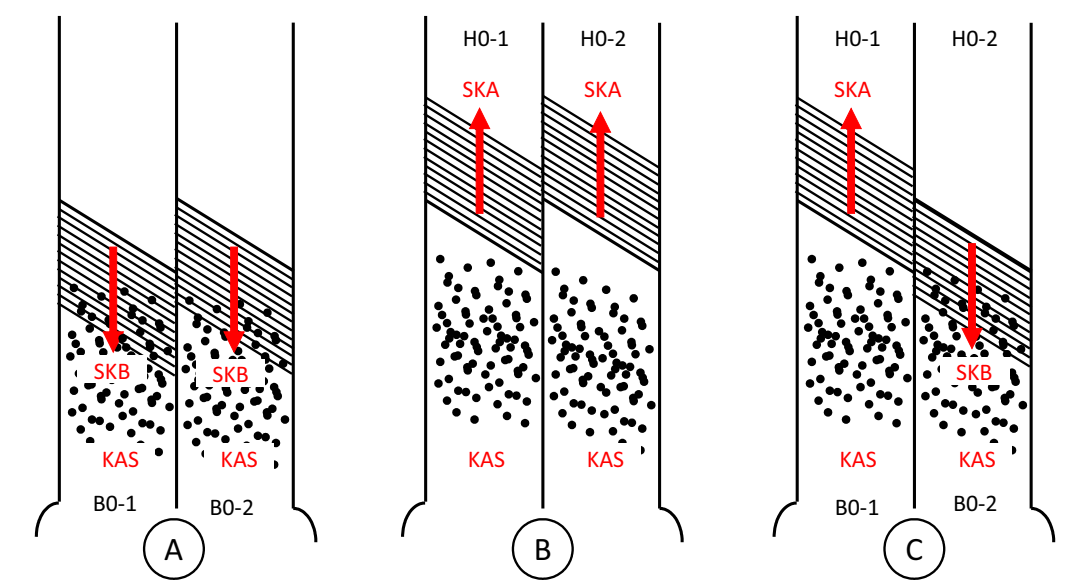

Keterangan:

$\mathrm{SKB}=$ sistem sadap ke arah bawah; $\mathrm{SKA}=$ sistem sadap ke arah atas; KAS = kering alur sadap

Gambar 4. Terputusnya aliran lateks menyebabkan terjadinya KAS pada panel di bawahnya

Penemuan lain yang dilakukan oleh Yeang et al. (1994) menyatakan keberadaan kandungan tembaga yang cukup tinggi pada lateks diketahui menjadi penyebab awal gejala KAS. Klon-klon yang rentan terserang KAS cenderung memiliki kandungan tembaga $(\mathrm{Cu})$ yang tinggi pada fase awal gejala KAS. Menurut Leiwakasbessy et al. (2003) unsur tembaga $(\mathrm{Cu})$ berfungsi sebagai aktivator enzim tyrosinase, laktase, oksidase asam askorbat transpor elektron pada fotosintesis. Namun penelitian tersebut berbeda dengan Sivakumaran et al. (2002) ; Andriyanto dan Tistama (2014) yang menyatakan bahwa kandungan hara tembaga pada tanaman KAS cenderung lebih rendah dan kaitan konsentrasi tembaga terhadap kejadian KAS juga belum dapat diketahui secara rinci.

\section{Pengendalian Kering Alur Sadap}

Berdasarkan kajian fisiologi, morfologi maupun ekonomis, kejadian KAS memberikan dampak negatif bagi tanaman. Kegiatan pengendalian KAS secara terpadu perlu dilakukan agar dapat mencegah dan mengurangi kerugian yang terjadi. Pengendalian KAS terpadu tersebut meliputi:
1. Komposisi dan pemilihan klon

KAS utamanya terjadi karena over tapping sehingga jumlah lateks yang dihasilkan tidak sesuai dengan potensi fisiologis tanaman. Hal ini terjadi karena tuntutan produksi yang hanya berorientasi pada pencapaian margin keuntungan tinggi tanpa memperhatikan faktor potensi klon dan umur tanaman. Boerhendhy dan Khaidir (2011) menyampaikan bahwa stabilitas produksi suatu kebun ditentukan oleh komposisi areal berdasarkan jenis klon dan umur tanaman. Luas areal peremajaan yang ideal adalah $4 \%$ dari total areal kebun dan dilaksanakan setiap tahun secara berkesinambungan.

Pemilihan klon sebaiknya dilakukan dengan mempertimbangkan potensi dan pola produksi, serta kesesuaian agroklimat setempat, sehingga pekebun lebih mudah memperkirakan target produksi dan menjaga stabilitasnya. Terkadang produksi suatu klon belum mencapai target yang sesuai, namun pada klon lain telah melewati batas optimalnya. Oleh karena itu, dengan memperhatikan komposisi umur dan klon diharapkan dapat menghindari pencapaian produksi yang tidak sesuai dengan potensi tanaman (over tapping) dan meminimalisir terjadinya KAS. 


\section{Sistem sadap}

Banyaknya kejadian KAS sebagian besar disebabkan oleh praktek penyadapan yang berlebihan. Penerapan sistem sadap normatif pada tanaman sehat berdasarkan tipologi klon dapat mencegah terjadinya KAS. Apabila gejala KAS mulai terlihat dalam suatu blok tanaman maka pekebun perlu segera melakukan pengamatan lebih dini dan intensif. Apabila intensitas KAS telah mencapai $>2,5 \%$, maka intensitas sadap dan pemberian stimulan perlu dikurangi. Apabila intensitas KAS telah mencapai > 5\%, maka kegiatan penyadapan sebaiknya dihentikan sementara waktu dan dilakukan pengobatan. Penggunaan sistem sadap sesuai tipologi klon dengan frekuensi penyadapan yang tepat disertai irisan sadap normatif dan penggunaan stimulansia yang selektif dapat mengurangi intensitas terjadinya KAS. Sistem penyadapan hendaknya mengacu pada kondisi fisiologi tanaman. Analisa parameter fisiologi dapat dilakukan untuk menentukan sistem sadap yang sesuai. Analisa parameter fisiologi tersebut antara lain kandungan sukrosa, tiol dan fosfat anorganik (Pi) pada lateks.

\section{Tataguna panel}

Tataguna panel merupakan salah satu bagian dari manajemen produksi tanaman karet yang berkaitan dengan konsumsi kulit pada panel tertentu. Tataguna panel bertujuan menggali potensi produksi disetiap bagian kulit secara optimal. Tataguna panel yang tidak tepat dapat menimbulkan dampak komplikasi. Irisan sadap disatu bagian kulit dapat menurunkan bahkan mematikan potensi produksi dibagian kulit lainnya. Dalam hal ini walaupun kulit masih tersedia, hasilnya akan nihil karena sudah terjadi efek saling memutus pada jaringan lateks (Sumarmadji, et al., 2015).

Pada saat ini tataguna panel dari suatu sistem sadap telah direkomendasikan agar sesuai dengan tipologi klon karet, yaitu sistem sadap pada klon quick starter (QS) dan slow starter(SS) (Sumarmadji, 2000 ; Sumarmadji et al., 2006). Penentuan tataguna panel tersebut, antara lain telah mempertimbangkan karakteristik metabolisme klon karet, kondisi kulit pulihan, respon terhadap stimulan dan tekanan sadapan, sehingga dapat menjamin kesinambungan pencapaian produksi dan meminimalisir terjadinya KAS.

Pada klon QS diterapkan tataguna panel tanpa memanfaatkan kulit pulihan untuk disadap kembali karena kecenderungan kulit pulihannya tipis, sedangkan pada klon SS kulit pulihan umumnya tebal sehingga potensial untuk dimanfaatkan (Siregar et al., 2008) (Gambar 5). Tataguna panel tersebut telah didesain sedemikian rupa untuk menghindari efek saling memutus jaringan lateks. Meskipun demikian, jika konsumsi kulit tidak terkendali dan cendeung boros, misalnya pada panel B0-1 klon SS disadap $<5$ tahun, maka regenerasi kulit pulihannya akan lambat dan cenderung tipis, sehingga ketika B0-2 disadap tidak menghasilkan produksi yang optimum. Hal tersebut dikarenakan kulit pulihan pada B0-1 (B1-1) masih tipis dan kurang dapat menopang kesinambungan aliran lateks dari source (daun dan B1-1) ke sink(B0-2).
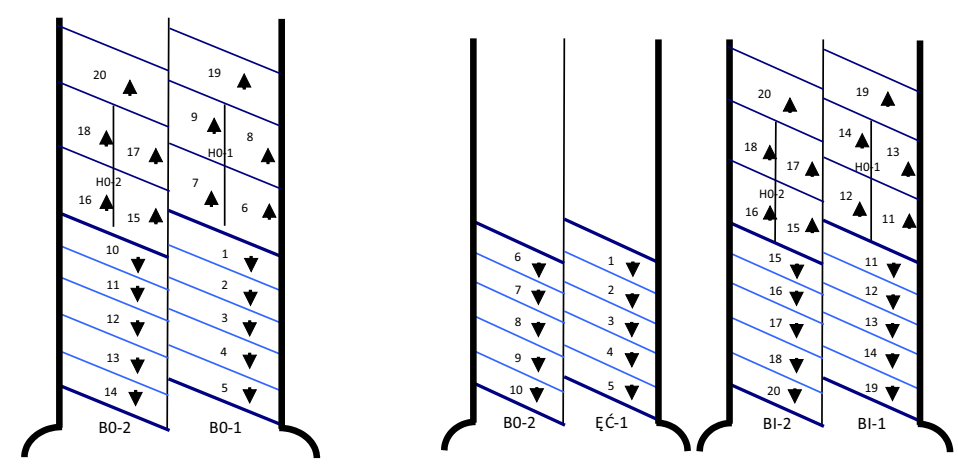

Gambar 5. Tataguna panel pada klon QS (kiri) dan SS (kanan) 


\section{Deteksi dini kondisi fisiologis}

Cara memonitor kondisi fisiologis tanaman karet dapat dilakukan dengan diagnosis lateks yang terjadwal setidaknya dua kali dalam setahun. Diagnosis lateks dilakukan guna mengetahui kondisi tanaman apakah dalam keadaan sehat atau telah mengalami kelelahan.

\section{Pemeliharaan tanaman}

Pemberian kalium dengan dosis tinggi mampu mengurangi kemunculan gejala serangan KAS pada kondisi tanah kering dan miskin hara (Sivakumaran et al., 1994). Istianto dan Munthe (2003) menyampaikan bahwa tanaman yang dipelihara dengan baik dan tercukupi kebutuhan nutrisinya melalui pemupukan yang tepat akan jauh dari gangguan KAS. Keseimbangan proporsi nutrisi baik makro (N, P, K, Ca, Mg, S) maupun mikro $(\mathrm{Fe}, \mathrm{B}, \mathrm{Zn}, \mathrm{Cu})$ sangat menentukan proses fisiologis tanaman. Baik unsur hara makro dan mikro sangat dibutuhkan tanaman karet khususnya dalam proses biosintesis lateks di jaringan pembuluh lateks. Ketersediaan unsur hara yang kurang optimal dan ketidak seimbangan sumbangan hara pada tanaman diduga dapat memicu munculnya gangguan KAS. Oleh karena itu, pemenuhan kebutuhan unsur yang seimbang dan sesuai kebutuhan tanaman diharapkan dapat menekan muculnya kejadian gangguan KAS

\section{Penyembuhan KAS}

Pembentukan sel tilosoid di dalam jaringan pembuluh lateks menyebabkan terjadinya penyumbatan, sehingga lateks tidak dapat mengalir keluar. Tanaman baru dapat disadap dan mengeluarkan lateks apabila jaringan kulit baru telah tumbuh. Salah satu cara untuk mempercepat pertumbuhan kulit baru (kulit pulihan) adalah dengan pengerokan kulit, yaitu membuang bagian kulit pada bidang sadap yang kering sampai jarak beberapa mili meter menjelang kambium.Selanjutnya kulit yang sudah dikerok dioles dengan formulasi oleokimia (Budiman dan Kuswanhadi, 1996) dan tidak disadap sampai kulit pulihan pulih kembali.

\section{Kesimpulan dan Saran}

Kering Alur Sadap (KAS) adalah gangguan fisiologis tanaman karet yang ditandai dengan tidak keluarnya lateks pada saat pohon disadap. Kejadian KAS terutama disebabkan oleh kelelahan fisiologis tanaman akibat praktek penyadapan intensitas tinggi dalam periode cukup panjang. Penyadapan dengan intensitas tinggi memicu aktivitas enzim enzim degradatif seperti $\mathrm{NAD}(\mathrm{P}) \mathrm{H}$-oksidase yang berdampak terhadap kerusakan lutoid, sehingga lateks mengalami penggumpalan dalam sel - sel pembuluh lateks. Upaya pencegahan KAS dapat dilakukan melalui penggunaan klon yang sesuai, praktek penyadapan disesuaikan dengan tipologi dan dilakukan secara normatif, penerapan tataguna kulit yang tepat, dan pemeliharaan tanaman. Tanaman yang mengalami KAS parsial dapat disembuhkan dengan perlakuan istirahat sadap selama beberapa waktu. Penyembuhan KAS total dapat dipercepat dengan pengerokan kulit dan pengolesan bahan oleokimia untuk mempercepat terbentuknya kulit pulihan. Selain itu perlu deteksi dini KAS secara fisiologis dengan dilakukan analisa lateks yang terjadwal.

\section{Daftar Pustaka}

Alscher, R. G., Erturk, N., and Health, L. S. (2002). Role of superoxide dismustases (SODs) in controling oxidative stress in plants. Jurnal of Experiment Botani. 53, 13311341.

Andriyanto, M. dan Tistama, R. (2014). Perkembangan dan upaya pengendalian kering alur sadap (KAS) pada tanaman karet (Hevea brasiliensis). Warta Perkaretan, 33(2), 89-102.

Boerhendhy, I. dan Amypalupy, K. (2011). Optimalisasi produktivitas karet melalui penggunaan bahan tanam, pemeliharaan, sistem eksploitasi, dan peremajaan tanaman. Jurnal Penelitian dan Pengembangan Pertanian, 30(1), 23-30. 
Budiman, A. dan Kuswanhadi. (1996). Penanggulangan gejala kering alur sadap pada beberapa klon Anjuran. Warta Pusat Penelitian Karet, 15(3), 176- 183.

Chrestin, H. (1989). Physiology of rubber tree latex: Biochemical aspect of bark dryness induced by overstimulation of rubber tress with ethrel. Florida: CRC Press, Inc.

Dey, S. K. (2005). Variation of tapping panel dryness in Hevea brasiliensis trees in Tripura. International Workshop On Tapping Panel Dryness, Kottayam, November 2005.

Gorge, K.T., and Kuruvilla, C.J., (2000). By Products and Ancillary Source of Income. In: P.J. Gorge and C.J. Kuruvilla (Eds.), Natural Rubber Agro management and Crop Processing (pp 509-520). Kottayam : Rubber Research Institute of India.

Gomez, J.B., Hamzah, S., Ghandimathi, H., and Ho, L.H. (1990). Brown bast syndrome of hevea. part II: histological observations. Journal Natural Rubber Research, 5(2), 90101.

Hadi, H. (2008). Prinsip dasar sistem eksploitasi tanaman karet. Makalah in-house training. Pelatihan Sistem Eksploitasi Pada Perkebunan Karet. PT Perkebunan Nusantara VIII.

Istianto dan Munthe, H. (2003). Upaya peningkatan keseragaman tanaman karet tbm melalui pemupukan selektif. Prosiding Konferensi Agribisnis Karet Menunjang Industri Lateks dan Kayu, Medan, Desember 2003.

Jacob, J. L., Prevot, J.C., Roussel, D., Lacrotte, R., Serres, E., D'Auzac, J., Eschbach, J. M., and Omont, H. (1989). Yield limiting factor, latex physiology parameters, latex diagnosis and clonal typology. In : J. d' Auzac., J.L. Jacob., and H. Chrestin.(Eds.), Physiology of Rubber Latex (pp 345-382). Boca Raton: CRC Press Inc.

Jacob, J. L., Prevot, J. C., and Lacrotte, R. (1994). Tapping panel dryness in Hevea brasiliensis. Plantations Research, 1(3), 22-24.

Krishnakumar, R., Cornish, K., and Jacob, J. (2001). Rubber biosynthesis in tapping panel affected Hevea trees. Journal of Rubber Research, 4(2), 131-139.
Krishnakumar, R., Rithu, M., R., Sreelatha, S., and Jacob, J. (2005). Endogenous ethylene and oxidative stress in Hevea brasiliensis. In J.Jacob., R.Khrisnakumar., and M.M. Mathew.(Eds.), Tapping Panel Dryness of Rubber Trees (116-124). Kottayam : Rubber Research Institute of India.

Leiwakabessy, F.M., Wahjudin, U.M., dan Suwarno. (2003). Kesuburan tanah. Bogor: Jurusan Tanah Fakultas Pertanian IPB.

Lukman. (1994). Penggunaan sadapan ke arah atas untuk meningkatkan produksi tanaman karet pada iklim tipe-A di Sumatera Utara. Jurnal Penelitian Karet, 14(1), 70-83.

Nair, N. U., Nair, B. R., Thomas, M., and Gopalakrishan, J. (2004). Latex diagnosis in relation to exploitation system in clone RRII 105. Journal of Rubber Research, 7(2), $127-137$.

Paranjothy, K., Gomez, J. B., and Yeang, H.Y. (1976). Physiological aspect of brown bast development. Proceeding International of Rubber Conference. Kuala Lumpur, Oktober 1975.

Prawirosoemardjo, S., dan Setyawan, B. (2010). Pengendalian hama penyakit pada tanaman karet. Makalah Pelatihan. Pelatihan Budidaya Karet. Balai Penelitian Getas.

Pushpadas, M.V., Kochappan, N.K, Krishnakumar, M., and Karthikakutty, A.M. (1975). Brown bast and nutrition : A case study. Rubber Board Bulletin, 12(3), 83 88.

Siregar, T.H.S., Junaidi., Sumarmadji., Siagian, N., dan Karyudi. (2008). Perkembangan penerapan rekomendasi sistem eksploitasi tanaman karet di perusahaan besar negara. Prosiding Lokakarya Nasional Agribisnis Karet, Yogyakarta, Agustus 2008.

Siswanto., Sumarmadji., dan Situmorang, A. (2004). Status dan pengendalian penyakit kering alur sadap tanaman karet. Prosiding Pertemuan Teknis Strategi Pengelolaan Penyakit Tanaman Karet untuk Mempertahankan Potensi Produksi Mendukung Industri Perkaretan Indonesia Tahun 2020, Palembang, Oktober 2004. 
Siswanto. (1994). Mekanisme fisiologis yang berkaitan dengan produksi lateks Hevea brasiliensis. Buletin Bioteknologi Perkebunan, 1, 23-29.

Siswanto. (1997). Gejala awal, penyebaran dan cara penanggulangan kekeringan alur sadap pada beberapa klon karet anjuran. Warta Bioteknologi Perkebunan, 9(1), 2 - 15.

Sivakumaran, S., Ghandimathi, H., Hamzah, Z., Yusof, F., Hamzah, S., and Yeang, H.Y. (2002). Physiological and nutritional aspect in relation to the spontaneous development of tapping panel dryness in clone PB 260. Journal of Rubber Research, 5(3), 135-156.

Sivakumaran, S., Leong, S.K., Ghouse, M., and Sivandayan, K. (1994). Influence on some agronomic practice on tapping panel dryness in Hevea tress. IRRDB TPD Workshop of Academy Tropical Plant of South China. Hainan, Juli 1994.

Sumarmadji., Rouf, A., Aji, Y.B.S., dan Widyasari, T. (2015). Optimalisasi produksi dan penekanan biaya penyadapan dengan sistem sadap intensitas rendah. Makalah workshop upaya peningkatan produktivitas, efisiensi dan pengembangan produk hilir karet non ban untuk mengatasi harga karet yang rendah. Bogor, Desember 2015.

Sumarmadji., Junaidi., Atminingsih., Kuswanhadi., dan Rouf, A. (2012). Paket teknologi penyadapan untuk optimasi produksi sesuai tipologi klon. Prosiding Konferensi Nasional Karet, Yogyakarta, September 2012.

Sumarmadji., Karyudi., dan Siregar, T.H.S. (2006). Rekomendasi sistem eksploitasi pada klon quick starter dan slow starter serta penggunaan irisan ganda untuk meningkatkan produktivitas tanaman karet. Prosiding Lokakarya Nasional Budidaya Tanaman Karet. Medan, September 2006.

Sumarmadji., Junaidi, U., Karyudi., Siregar, T.H.S. and Boerhendy, I. (2004). Rubber exploitation system for Indonesian recommended clones based latex diagnosis. Proceeding International Rubber Conference and Product Exploitation, Jakarta, December 2004.
Sumarmadji. (2000). Sistem eksploitasi tanaman karet yang spesifik-diskriminatif. Warta Pusat Penelitian Karet, 19(1-3), 31-39.

Tistama, R., dan Siregar, T.H.S. (2005). Perkembangan penelitian stimulan untuk pengukuran lateks Hevea brasiliensis. Warta Perkaretan, 24(2), 45-57.

Tistama, R., Sumarmadji., dan Siswanto. (2006). Kejadian kering alur sadap (KAS) dan teknik pemulihannya pada tanaman karet. Prosiding Lokakarya Nasional Budidaya Tanaman Karet, Medan, September 2006.

Tjoet, V. D., Prevot, J.C., Jacob, J.L., and Clement, A.V. (2002). Both ascorbate peroxidase and glutathione peroxidase are active in removal of $\mathrm{H} 2 \mathrm{O} 2$ from cytosol of Hevea brasiliensis latex. Journal of Rubber Research, 5(4), 226-243.

Tupy, J. (1989). Sucrose supply and utilization for latex poduction. In J. d'Auzac., J.L. Jacob., and H.Chrestin (Eds.), Physiology of Rubber Tree Latex (pp180-198). Boca Raton : CRC Press.

Vijayakumar, K.R., Sulochanamma, S., Thomas, M., Sreelatha, S., Simon, S.P., and Sethuraj, M.R. (1991). The effect of intensive tapping on induction of tapping panel dryness and associated biochemical changes in two clones of Hevea. Proceedings of IRRDB Symposium Physiology Exploitation of Hevea brasiliensis, Kunming, Oktober 1990.

Yeang, H.Y., Sivakumaran, S., and Hamzah, Z. (1994). Latex Coper Content in Relation to the Onset of Tree Dryness. IRRDB TPD Workshop of Academy Tropical Plant of South China, Hainan, Juli 1994. 